\title{
Morphometric Characteristics of Cipeles Watershed to Identify Flood Prone Area
}

\author{
Pradnya Paramarta Raditya Rendra ${ }^{\mathrm{a}, *}$, Emi Sukiyah $^{\mathrm{b}}$ \\ ${ }^{a}$ Applied Geology Department, Universitas Padjadjaran, Sumedang, 45363, Indonesia \\ ${ }^{b}$ Science Geology Department, Universitas Padjadjaran, Sumedang, 45363, Indonesia \\ Corresponding author: *raditya.rendra@unpad.ac.id
}

\begin{abstract}
Cipeles watershed is located on Sumedang Regency, West Java Province. This research aims to identify the flood-prone area in the Cipeles Watershed based on morphometric characteristics. This research was conducted through studio analysis using Map Info and Global Mapper software and mathematical calculations. The data used in this research are stream network and topography. Digital Elevation Model was used to analyze the slope of the research area. Morphometric aspects used in the mathematical calculations consist of Drainage density, Drainage texture, Ratio of circularity, Ratio of elongation, and Form factor. The research area is a hilly area with high relief and a very steep-slightly steep slope in the west and south, relatively gentle in the middle to the east of the research area. It consists of parallel, subparallel, subradial, rectangular, dendritic, and subdendritic drainage patterns. Cipeles watershed has 38 subwatersheds with predominantly very elongated-circular shape and very coarse-coarse texture. The research area has relatively high rainfall that potentially causes flooding, especially downstream of the Cpl_10, Cpl_11, Cpl_12, Cpl_13, Cpl_14, Cpl_15, Cpl_16, and Cpl_17 subwatersheds. The research area is classified into low and moderate risk levels of flood potential. The low-risk level is located in Tanjungsari and Rancakalong district. The moderate risk level is located in North Sumedang, South Sumedang, Situraja, and Cimalaka district. The results showed that quantitative research could be used to identify flood prone area. It is recommended that the Cipeles Watershed can be well maintained through integrated watershed management and land use management.
\end{abstract}

Keywords-Morphology; drainage pattern; morphometric; floods; Cipeles watershed.

\section{INTRODUCTION}

Watershed is a natural hydrological entity from which surface run-off flows to a defined drain, channel, stream, or river at a particular point [1] that needs to be managed to maintain water availability. The research area is in the Cipeles Watershed at coordinates $6^{\circ} 45^{\prime} 17,1^{\prime \prime} \mathrm{S}-6^{\circ} 58^{\prime} 14,1^{\prime \prime} \mathrm{S}$ and $107^{\circ} 45^{\prime} 28,1^{\prime \prime} \mathrm{E}-108^{\circ} 6^{\prime} 23,6^{\prime \prime} \mathrm{E}$. It consists of Tanjungsari, Rancakalong, North Sumedang, South Sumedang, Cimalaka, Paseh, Situraja, and Tomo district in Sumedang Regency (Fig. 1). It needs to be a concern because the research area in Sumedang Regency is an important developing area. The land-use change in Cipeles Watershed (research area) showed decreased forest and shrub area losses up to 5\% every 10 years [2]. It can lead to increased floods [3], [4]. It is expected that massive development will not damage the environment, which can lead to flooding. Hence, scientific consideration through this research is needed for regional development to avoid flooding.
Morphometry is a quantification form of earth morphology, shape, and dimension [5], [6], and also one of the essential physical characteristics of watersheds [7]. Each morphometric aspect's value indicates a watershed characteristic such as slope characteristics, topography, and surface run-off that can be used in watershed management [6], [8]. Good watershed management through morphometric aspects approach can assist area development management [9].

Morphology, drainage pattern, morphometric, and rainfall are aspects studied in this research. Those aspects are interrelated and indicate the geological characteristic in the research area. The morphometric aspect used with the remote sensing method can indicate the Upper Cimanuk Watershed's geological characteristic in West Java Province [10] and Way Belu Watershed in Lampung Province [11]. Based on the geological characteristic, it is also expected that this can be used to provide an initial solution to overcome floods in the area. 
Morphology and morphometric characteristics of the watershed are essential and related to watershed hydrology [5], topography, and geology [12], [13]. The longer the watershed length, the steeper the topography, the higher the run-off, the more elongated watershed shape, means the younger the landform's erosion cycle [14], [15]. Therefore, morphology and morphometry are closely related which cannot be separated from one another.

Drainage patterns can reflect several characteristics of an area such as lithology, structure, slope, rock resistance, and sediment and water transport [13], [16]. Drainage patterns can be classified into basic patterns and modified basic patterns [17]. Some basic patterns such as dendritic, parallel, trellis, rectangular, and radial can be found in various regions.

In general, morphometry can be divided into 3 aspects: linear, areal, and relief morphometry. Each aspect has its own calculation parameters. In this research, the areal morphometric aspect is used and involves morphometric parameters such as Drainage density (Dd), Drainage texture (Dt), Ratio of Circularity (Rc), Ratio of Elongation (Re), and Form Factor (Rf). These parameters are used because many researchers [1], [8], [12], [18]-[23] have used the parameters to determine the character of an area, especially the potential for flooding in the watershed. However, research on watershed morphometry to identify flood-prone areas in the research area is inadequate. Meanwhile, research on watershed morphometry is essential and can provide benefits for policymakers in regional development.

The Cipeles Watershed consists of Tanjungsari, Rancakalong, North Sumedang, South Sumedang, Cimalaka, Paseh, Situraja, and Tomo district in Sumedang Regency. These areas are essential with massive development, so they need to be accompanied by protecting the environment. If these crucial areas are flooded, various economic activities can be paralyzed. It is expected that this will not happen. This research is critical to do as an effort to identify areas that are potentially flooded. Moreover, this research aims to identify the flood-prone area in the Cipeles Watershed based on morphometric aspects. Thus, the flood-prone area can be managed and developed correctly through regional development policies based on this research result.

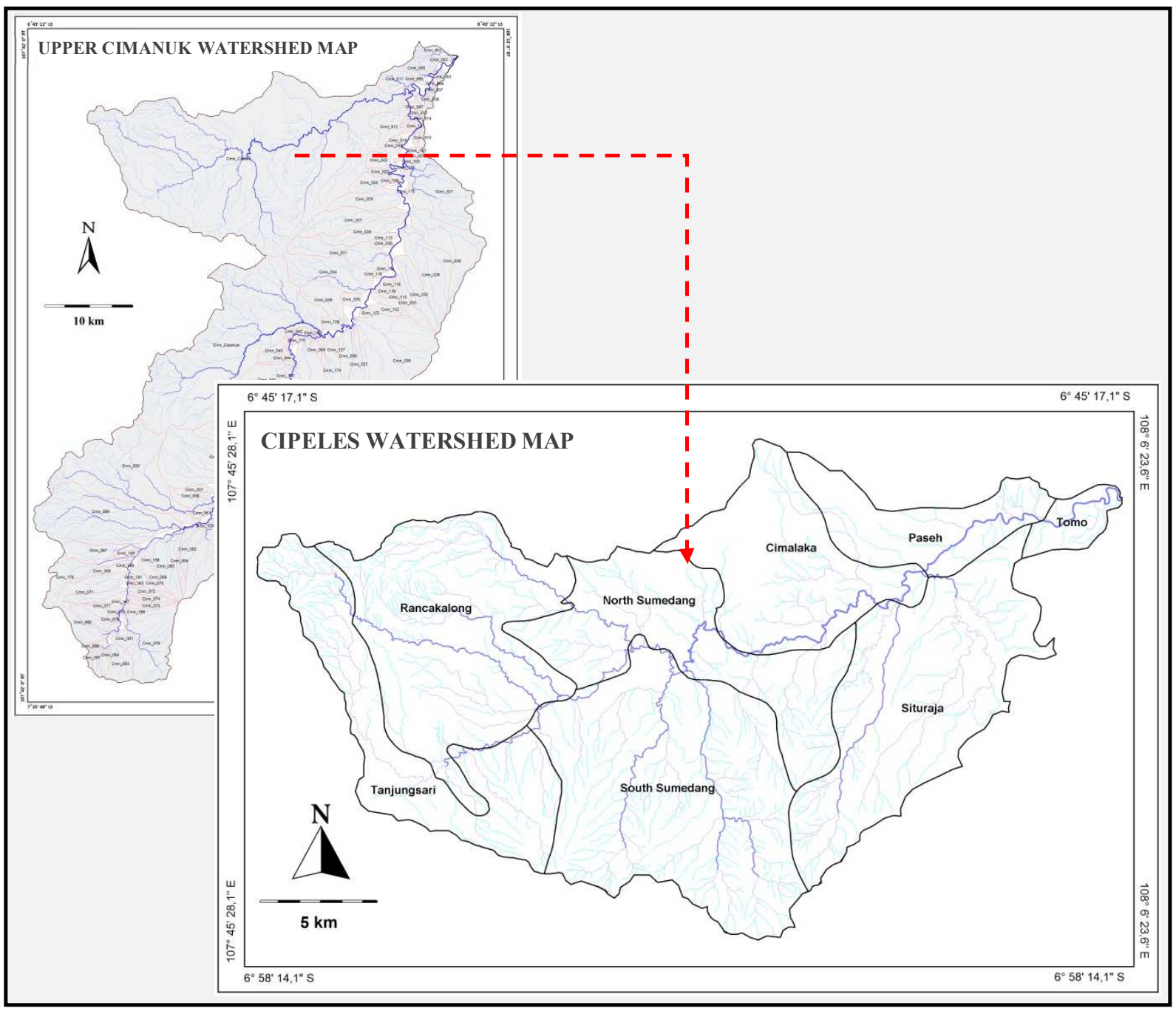

Fig. 1 The research area in the Cipeles Watershed 


\section{MATERIAL AND METHOD}

This research was conducted through studio analysis with the support of digital processing software, namely Map Info and Global Mapper. The data used in this research consist of stream network and topography obtained from Indonesia Topographic maps and Digital Elevation Model (DEM). DEM can be used to identify and recognize geological characteristics such as morphology [24], [25] and analyze the slope of the research area [23]. DEM is the primary dataset that can be used for morphometry analysis for many applications [12], [13], [26]. DEM dataset with remote sensing and GIS methods can be extracted to obtain drainage patterns or stream network [26], [27]. Morphometric aspects used in the calculations consist of areal morphometric such as Drainage density (Dd), Drainage texture (Rt), Ratio of circularity (Rc), Ratio of elongation (Re), and Form factor (Rf).

\section{A. Drainage Density $(\mathrm{Dd})$ and Drainage Texture (Dt)}

Drainage density (Dd) is a measure of the stream's total length in any drainage area or watershed [28] (see Table I).

TABLE I

\begin{tabular}{cc} 
DRAINAGE DENSITY CLASSIFICATION [30] \\
\hline $\mathbf{D}_{\mathbf{d}}$ & Class \\
$<2$ & Very coarse \\
$2-4$ & Coarse \\
$4-6$ & Moderate \\
$6-8$ & Fine \\
$>8$ & Very fine \\
\hline
\end{tabular}

Watersheds with higher Drainage density (Dd) values are prone to higher sediment yield values [13]. Higher Drainage density (Dd) also indicates steep terrain, sparse vegetation, less permeable surfaces, and low infiltration [20]. On the other hand, lower Drainage density (Dd) of a watershed indicates highly permeable subsurface condition, dense vegetation, and low relief [12], [13]. The value of Dd can be obtained using the equation below [28], [29].

$$
\mathrm{Dd}=\mathrm{L} / \mathrm{A}
$$

Where:

L: total length of the streams

A: area of drainage basin or watershed

Drainage texture $(\mathrm{Dt})$ is the number of stream segments of all orders in the drainage area's perimeter or watershed [29] (see Table II).

TABLE II

DRAinage TEXTURE ClassifiCATION [30]

\begin{tabular}{cc}
\hline $\mathbf{D}_{\mathbf{t}}$ & Class \\
\hline$<4$ & Coarse \\
$4-10$ & Intermediate \\
$10-$ & Fine \\
15 & \\
$>15$ & Very Fine \\
\hline
\end{tabular}

Low drainage density indicates coarse drainage texture, while high drainage density indicates fine drainage texture [1],
[28]. In general, the drainage density and drainage texture are significantly correlated [29]. The value of Dt can be obtained using the following equation [29]:

$$
\mathrm{Dt}=\mathrm{Nu} / \mathrm{P}
$$

Where:

$\mathrm{Nu}$ : total number of streams of all orders

P: perimeter of drainage basin or watershed

\section{B. Ratio of Circularity (Rc), Ratio of Elongation (Re), and Form Factor ( $R f)$}

Determination of a drainage area or watershed shape can be done using parameters, namely Ratio of circularity (Rc), Ratio of elongation (Re), and Form factor (Rf). The shape of a watershed can be classified into elongated and circular shape. However, detailed calculations can use the parameter above. Each parameter has its classification. Ratio of circularity $(\mathrm{Rc})$ is the ratio between the watershed area to the watershed perimeter [28]. Low Rc value $(<0.5)$ indicates the elongated shape of a watershed, while high $\mathrm{Rc}$ value $(>0.5)$ indicates the circular shape of a watershed [8]. The low Rc value indicates a low risk of the flash flood, while the high Rc value indicates a high risk of the flash flood [18], [20], [31]. The low Rc value is associated with the youth stage of a watershed, while the high Rc value is associated with the mature stage of a watershed [16]. On the other hand, the watershed shape, which is characterized by the Ratio of circularity (Rc) is influenced by the lithological characteristics of the watershed [15], [20]. The value of Rc can be obtained using equation below [28].

Where:

$$
\mathrm{Rc}=4 \pi \mathrm{A} / \mathrm{P}^{2}
$$

A: area of drainage basin or watershed

P: perimeter of drainage basin or watershed

The ratio of elongation $(\mathrm{Re})$ is the ratio between a watershed area and a watershed length [32]. The ratio of elongation classification can be seen in Table III. A circular drainage basin or watershed, which can be seen from the higher Re values, indicates a high infiltration rate and low run-off in the watershed, while an elongated drainage basin or watershed, which can be seen from the lower Re values, indicates a low infiltration rate and high run-off [13]. The value of Re can be obtained using the equation below [32].

$$
\operatorname{Re}=2 \sqrt{(A / \pi) / L b}
$$

Where:

A: area of drainage basin or watershed $\mathrm{Lb}$ : length of river basin or watershed

TABLE III

RATIO OF ELONGATION CLASSIFICATION [28]

\begin{tabular}{cc}
\hline Re & Class \\
\hline$<0.5$ & Very elongated \\
$0.5-0.7$ & Elongated \\
$0.7-0.8$ & Less elongated \\
$0.8-0.9$ & Oval \\
$0.9-1.0$ & Circular \\
\hline
\end{tabular}


Form factor (Rf) is the ratio between the drainage basin area or watershed to the square of the river basin's length or watershed [29]. The form factor is closely related to the circularity ratio and elongation ratio. The smaller the value of a form factor, the more elongated a watershed shape. The value of Rf can be obtained using the equation below [29].

$$
\mathrm{Rf}=\mathrm{A} /(\mathrm{Lb})^{2}
$$

Where:

A: area of drainage basin or watershed

Lb: length of river basin or watershed

\section{Rainfall}

Rainfall can be a trigger for flooding, especially during the rainy season. High rainfall can provide a large water supply to the ground. The water supply can infiltrate into the ground and become groundwater or flow on the surface and become surface run-off. High rainfall also makes the ground condition saturated so that it has the potential to cause flooding. The heavy rainfall rates (around $3000 \mathrm{~mm} /$ year) may result in sediment transport and floods, and debris flows [33]-[35].

Rainfall in the research area is related to climate conditions in Indonesia over a certain period. During the period, rainfall can indicate the condition of fluctuation in rainfall due to climate influences. Global warming causes climate change, irregular dry and rainy seasons [36], [37]. Therefore, the mean annual rainfall for the 30 years (1961-1990) data is needed to estimate rainfall distribution in the research area.

\section{RESULTS AND DISCUSSION}

\section{A. Morphology and Drainage Pattern}

The morphological condition of the research area can be seen in Figure 2. The research area is hilly in the west and south with high relief and a very steep-slightly steep slope. In the middle to the east of the research area (towards the downstream), the morphology is relatively gentle, and it still shows a few small hills with slopes that are not too steep.

It shows that in the western and southern parts of the research area, the potential for flooding is relatively small. However, in the middle of the research area with a relatively gentle slope, it can cause flooding. Gentle slopes accelerate the high accumulation of water in a long time. If high rainfall occurs upstream of each subwatershed, then flooding can occur in each subwatershed downstream, especially at the gentle slope areas.

Cipeles river is the main river in the research area. The research area consists of parallel, subparallel, subradial, rectangular, dendritic, and subdendritic drainage pattern (Fig. 3 and Table IV). Most of the research areas with parallel and subradial drainage patterns have relatively lower flooding potential, such as at the Cpl_01, Cpl_02, and Cpl 20 subwatersheds subparallel dendritic, and subdendritic drainage pattern, for example, at the Cpl_04, Cpl_10, and Cpl_26. Most of the subparallel, dendritic, and subdendritic drainage patterns are located on a relatively steep, gentle slope area.

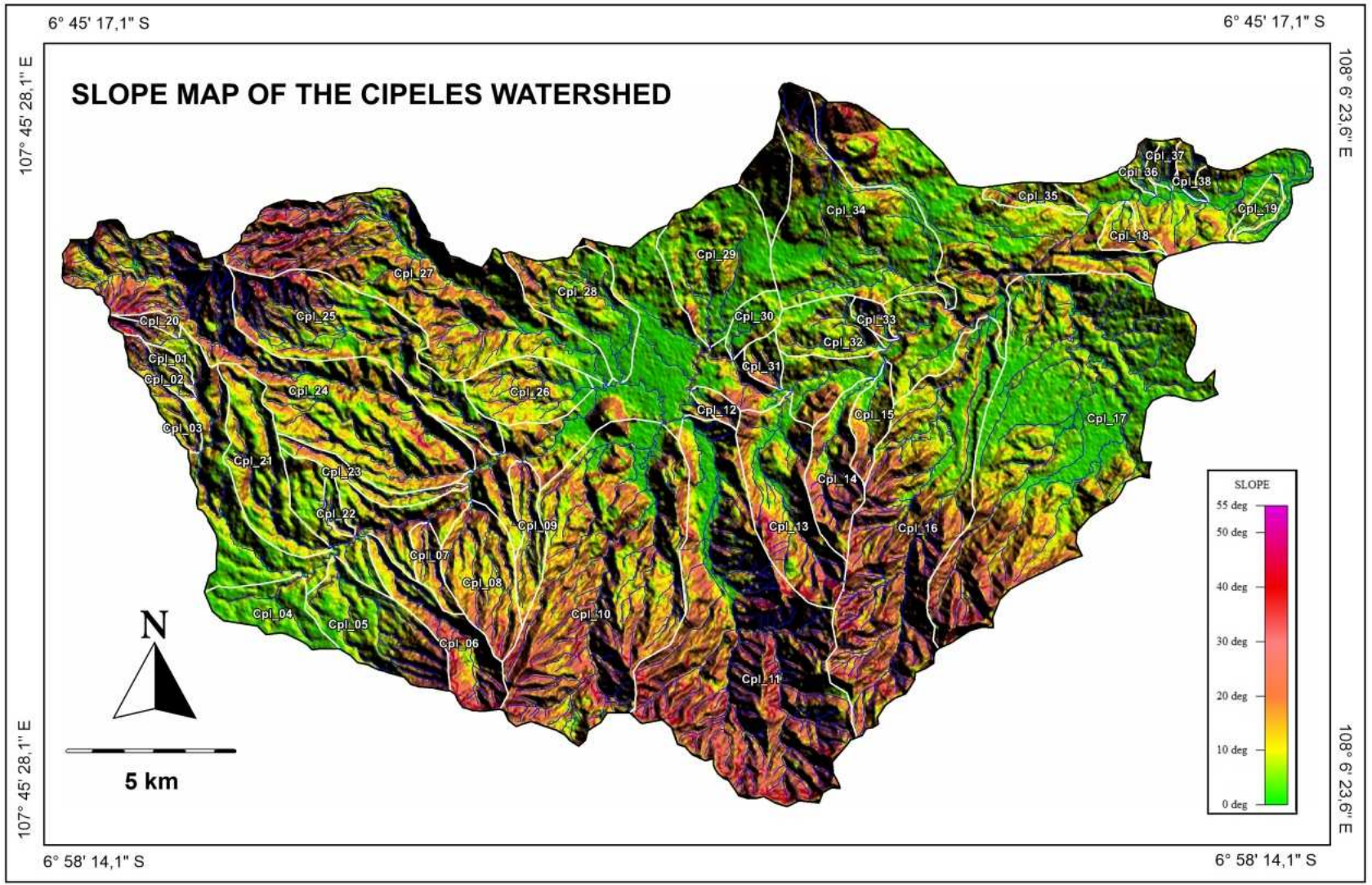

Fig. 2 Slope map of the research area 


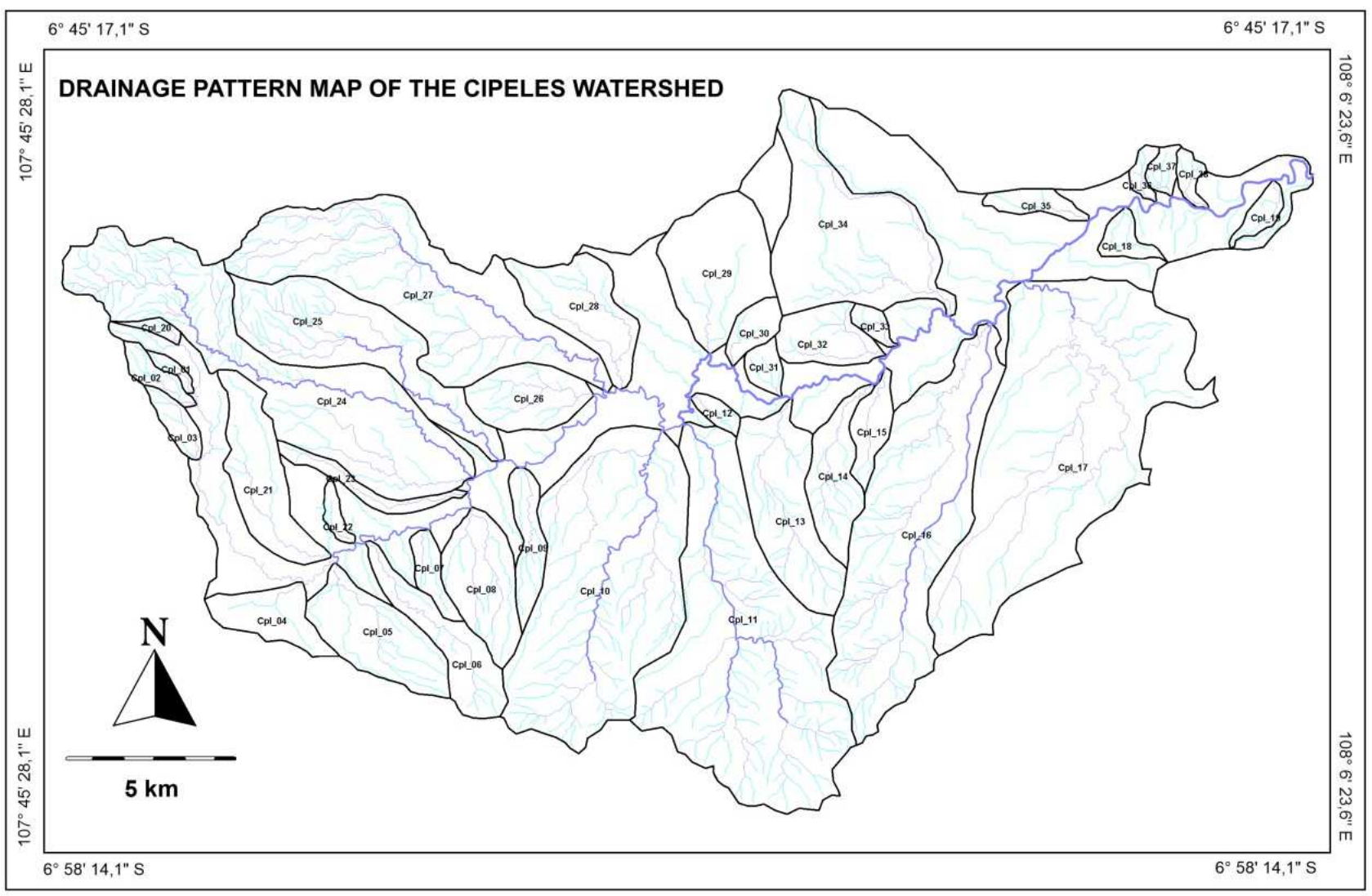

Fig. 3 Drainage pattern map of the research area

\section{B. Drainage Density $(\mathrm{Dd})$ and Drainage Texture (Dt)}

The Drainage density (Dd) values in the research area ranged from 0.73-4.05 (Table IV). In general, it indicates that all of the Cipeles subwatershed have very coarse-coarse drainage density. It also indicates that the research area's characteristic is not much different between subwatersheds with the relatively permeable subsurface condition, reasonably dense vegetation, and low-high relief.

There was not much difference from Drainage density (Dd) values; the Drainage texture (Dt) values in the research area are classified into a coarse texture. It can be proven from the calculation results in Table IV, the Drainage texture (Dt) value ranged from $0.23-3.84$. It indicates that all of the Cipeles subwatershed have coarse drainage texture. It indicates that all of the subwatershed surface run-off and erosion potential are relatively moderate.

\section{Ratio of Circularity (Rc), Ratio of Elongation (Re), and Form Factor (Rf)}

The Ratio of circularity ( $\mathrm{Rc}$ ) in the research area ranged from 0.17-0.82. It can be seen in Table IV. It shows that the subwatersheds in the research area are elongated-circular shaped. The distribution of subwatersheds shape based on the circularity ratio is quite varied. For example, the circularity ratio of Cpl_01, Cpl_02, and Cpl_06 subwatersheds are 0.41, 0.46 , and 0.36 , respectively, while Cpl_04, Cpl_05, and Cpl_08 subwatersheds are $0.51,0.65$, and 0.70 , respectively.

The Ratio of elongation ( $\mathrm{Re})$ in the research area ranged from 0.27-1.07. It can be seen in Table IV. It shows that the subwatersheds in the research area are very elongated-circular shaped. The distribution of subwatersheds shape based on the elongation ratio varies greatly. The subwatershed shape is quite related to the drainage pattern. For example, most elongated subwatersheds have parallel drainage patterns, while the less elongated-circular subwatersheds have subparallel, subradial, and dendritic drainage pattern.

There is no prominent difference among Ratio of circularity (Rc), Ratio of elongation (Re), and the Form factor (Rf), indicating that similarity of subwatersheds shape takes place. The form factor values of sub-watersheds in the research area are 0.06-0.89. It can be seen in Table IV. It indicates the subwatersheds have elongated-circular shapes.

A circular subwatershed indicates a more active denudational process, high infiltration capacity, and low runoffs such as Cpl_04, Cpl_10, and Cpl_26 sub-watersheds, while an elongated subwatershed indicates high susceptibility to erosion and sediment loads such as Cpl_01, Cpl_02, and Cpl_20 sub-watersheds.

\section{Rainfall}

The rainfall condition of the research area is shown in the rainfall map of the research area. It can be seen in Fig. 4. Based on the research area's rainfall map, the intensity of rainfall in the research area ranges between 2.000-4.000 $\mathrm{mm} /$ year. South Sumedang, North Sumedang, and Situraja district have a large rainfall range. It indicates that the areas have a relatively high rainfall so that it can potentially cause flooding, especially in the downstream of the Cpl_10, Cpl_11, Cpl_12, Cpl_13, Cpl_14, Cpl_15, Cpl_16, and Cpl_17 subwatersheds. 


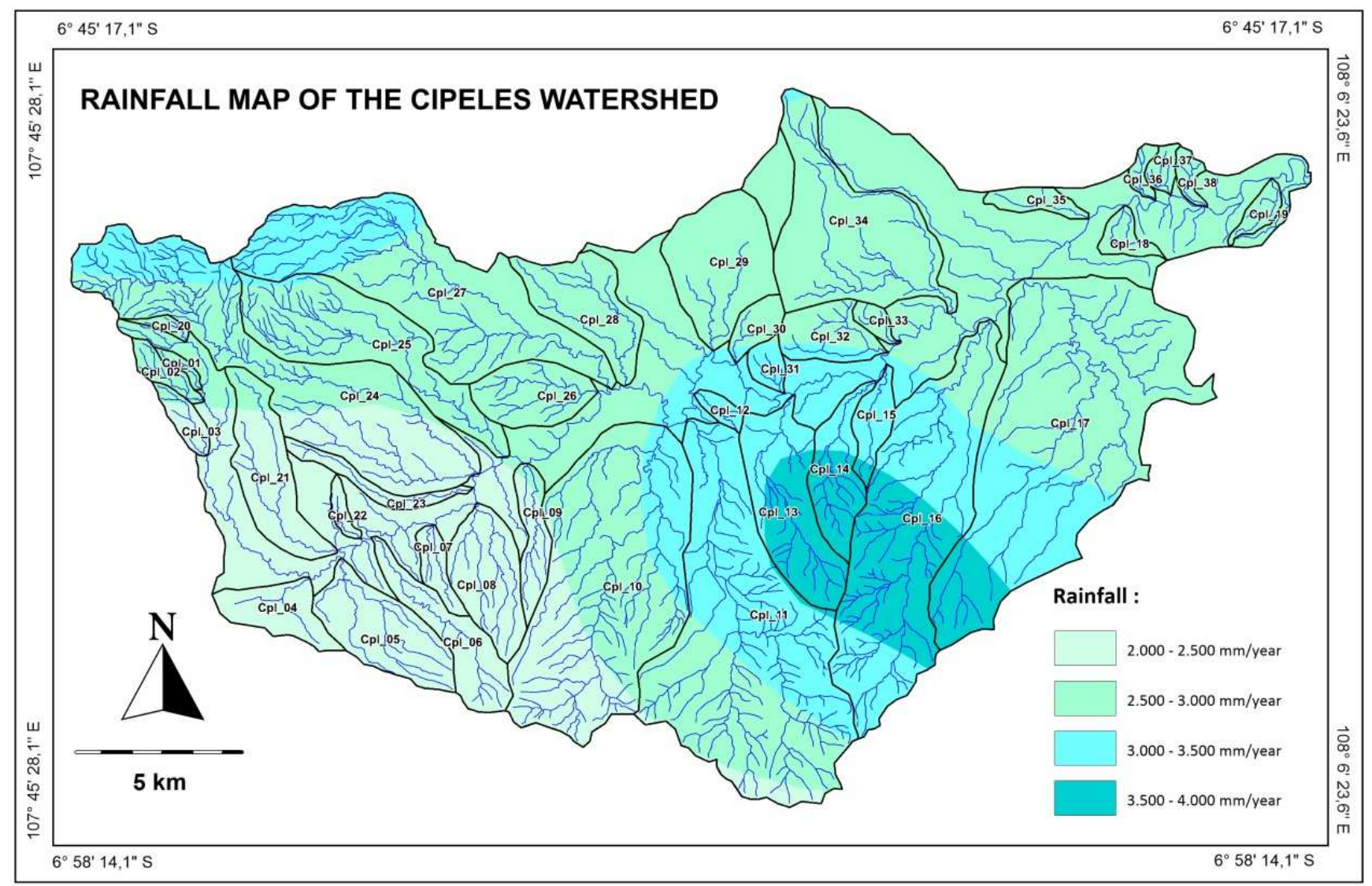

Fig. 4 Rainfall map of the research area

TABLE IV

MORPHOLOGY AND MORPHOMETRIC ASPECTS OF THE CIPELES WATERSHED

\begin{tabular}{|c|c|c|c|c|c|c|c|c|c|c|}
\hline $\begin{array}{l}\text { Sub } \\
\text { watershed }\end{array}$ & Slope & $\begin{array}{l}\text { Drainage } \\
\text { Pattern }\end{array}$ & Dd & Dt & $\begin{array}{l}\text { Basin } \\
\text { Texture }\end{array}$ & Re & $\mathbf{R e}$ & $\mathbf{R f}$ & Basin Shape & $\begin{array}{l}\text { Flood } \\
\text { Potential }\end{array}$ \\
\hline Cpl_01 & Steep & Parallel & 4.05 & 0.70 & Coarse & 0.41 & 0.44 & 0.15 & $\begin{array}{l}\text { Elongated-very } \\
\text { elongated }\end{array}$ & Low \\
\hline Cpl_02 & Steep & Parallel & 3.91 & 0.92 & Coarse & 0.46 & 0.47 & 0.18 & $\begin{array}{l}\text { Elongated- very } \\
\text { elongated }\end{array}$ & Low \\
\hline Cpl_03 & $\begin{array}{l}\text { Steep- } \\
\text { slightly steep }\end{array}$ & Parallel & 2.94 & 0.82 & Coarse & 0.56 & 0.52 & 0.21 & Circular-elongated & Low \\
\hline Cpl_04 & Gentle & Subradial & 1.05 & 0.28 & $\begin{array}{l}\text { Very coarse- } \\
\text { coarse }\end{array}$ & 0.51 & 1.07 & 0.89 & Circular & Moderate \\
\hline Cpl_05 & $\begin{array}{l}\text { Steep- } \\
\text { gentle }\end{array}$ & Subparallel & 2.49 & 0.85 & Coarse & 0.65 & 0.60 & 0.28 & Circular-elongated & Moderate \\
\hline Cpl_06 & $\begin{array}{l}\text { Steep- } \\
\text { more gentle }\end{array}$ & Parallel & 2.09 & 0.60 & Coarse & 0.36 & 0.43 & 0.14 & $\begin{array}{l}\text { Elongated- } \\
\text { very elongated }\end{array}$ & Low \\
\hline Cpl_07 & $\begin{array}{l}\text { Steep- } \\
\text { slightly steep }\end{array}$ & Parallel & 2.89 & 0.56 & Coarse & 0.46 & 0.47 & 0.18 & $\begin{array}{l}\text { Elongated-very } \\
\text { elongated }\end{array}$ & Low \\
\hline Cpl_08 & $\begin{array}{l}\text { Steep- } \\
\text { more gentle }\end{array}$ & Subparallel & 2.61 & 1.13 & Coarse & 0.70 & 0.61 & 0.30 & Circular-elongated & Moderate \\
\hline Cpl_09 & $\begin{array}{l}\text { Slightly steep- } \\
\text { more gentle }\end{array}$ & Parallel & 3.21 & 0.55 & Coarse & 0.35 & 0.41 & 0.13 & $\begin{array}{l}\text { Elongated-very } \\
\text { elongated }\end{array}$ & Low \\
\hline Cpl_10 & $\begin{array}{l}\text { Very steep- } \\
\text { gentle }\end{array}$ & $\begin{array}{l}\text { Subradial } \\
\text { Subparallel }\end{array}$ & 2.58 & 3.00 & Coarse & 0.67 & 0.70 & 0.38 & Circular-elongated & Moderate \\
\hline Cpl_11 & $\begin{array}{l}\text { Very steep- } \\
\text { gentle }\end{array}$ & $\begin{array}{l}\text { Dendritic } \\
\text { Subdendritic } \\
\text { Rectangular }\end{array}$ & 2.67 & 3.84 & Coarse & 0.49 & 0.59 & 0.27 & Elongated & Moderate \\
\hline Cpl_12 & Steep-gentle & Subparallel & 3.00 & 0.94 & Coarse & 0.65 & 0.64 & 0.32 & Circular-elongated & Moderate \\
\hline Cpl_13 & $\begin{array}{l}\text { Very steep- } \\
\text { gentle }\end{array}$ & Subparallel & 2.32 & 1.39 & Coarse & 0.52 & 0.54 & 0.23 & Circular-elongated & Moderate \\
\hline
\end{tabular}




\begin{tabular}{|c|c|c|c|c|c|c|c|c|c|c|}
\hline Cpl_14 & Steep-gentle & Subparallel & 2.52 & 1.14 & Coarse & 0.41 & 0.44 & 0.15 & $\begin{array}{l}\text { Elongated-very } \\
\text { elongated }\end{array}$ & Moderate \\
\hline Cpl_15 & Steep-gentle & Parallel & 1.70 & 0.35 & $\begin{array}{l}\text { Very coarse- } \\
\text { coarse }\end{array}$ & 0.45 & 0.51 & 0.20 & Elongated & Moderate \\
\hline Cpl_16 & $\begin{array}{l}\text { Very steep- } \\
\text { gentle }\end{array}$ & $\begin{array}{l}\text { Subparallel } \\
\text { Subdendritic }\end{array}$ & 2.51 & 2.53 & Coarse & 0.42 & 0.47 & 0.17 & $\begin{array}{l}\text { Elongated-very } \\
\text { elongated }\end{array}$ & Moderate \\
\hline Cpl_17 & Steep-gentle & $\begin{array}{l}\text { Subparallel } \\
\text { Subdendritic }\end{array}$ & 1.72 & 1.15 & $\begin{array}{l}\text { Very coarse- } \\
\text { coarse }\end{array}$ & 0.47 & 0.57 & 0.26 & Elongated & Moderate \\
\hline Cpl_18 & $\begin{array}{l}\text { Slightly steep- } \\
\text { gentle }\end{array}$ & Subparallel & 2.33 & 0.48 & Coarse & 0.50 & 0.57 & 0.25 & Circular-elongated & Moderate \\
\hline Cpl_19 & $\begin{array}{l}\text { More gentle- } \\
\text { gentle }\end{array}$ & Dendritic & 2.96 & 0.70 & Coarse & 0.51 & 0.52 & 0.21 & Elongated & Moderate \\
\hline Cpl_20 & Steep & Parallel & 3.49 & 0.62 & Coarse & 0.34 & 0.39 & 0.12 & $\begin{array}{l}\text { Elongated-very } \\
\text { elongated }\end{array}$ & Low \\
\hline Cpl_21 & $\begin{array}{l}\text { Slightly steep- } \\
\text { more gentle }\end{array}$ & Parallel & 1.55 & 0.32 & $\begin{array}{l}\text { Very coarse- } \\
\text { coarse }\end{array}$ & 0.43 & 0.45 & 0.16 & $\begin{array}{l}\text { Elongated-very } \\
\text { elongated }\end{array}$ & Low \\
\hline Cpl_22 & $\begin{array}{l}\text { Slightly steep- } \\
\text { more gentle }\end{array}$ & Parallel & 3.64 & 0.61 & Coarse & 0.45 & 0.45 & 0.16 & $\begin{array}{l}\text { Elongated-very } \\
\text { elongated }\end{array}$ & Low \\
\hline Cpl_23 & $\begin{array}{l}\text { Steep- } \\
\text { more gentle }\end{array}$ & Parallel & 2.91 & 0.23 & Coarse & 0.17 & 0.27 & 0.06 & $\begin{array}{l}\text { Elongated-very } \\
\text { elongated }\end{array}$ & Low \\
\hline Cpl_24 & $\begin{array}{l}\text { Very steep- } \\
\text { more gentle }\end{array}$ & $\begin{array}{l}\text { Subradial } \\
\text { Subparallel }\end{array}$ & 2.90 & 2.55 & Coarse & 0.32 & 0.44 & 0.15 & $\begin{array}{l}\text { Elongated-very } \\
\text { elongated }\end{array}$ & Low \\
\hline Cpl_25 & $\begin{array}{l}\text { Very steep- } \\
\text { more gentle }\end{array}$ & $\begin{array}{l}\text { Subradial } \\
\text { Subparallel }\end{array}$ & 2.89 & 1.79 & Coarse & 0.35 & 0.43 & 0.14 & $\begin{array}{l}\text { Elongated-very } \\
\text { elongated }\end{array}$ & Low \\
\hline Cpl_26 & $\begin{array}{l}\text { Slightly steep- } \\
\text { gentle }\end{array}$ & Dendritic & 2.38 & 1.69 & Coarse & 0.82 & 0.69 & 0.38 & Circular-elongated & Moderate \\
\hline Cpl_27 & $\begin{array}{l}\text { Very steep- } \\
\text { gentle }\end{array}$ & $\begin{array}{l}\text { Subradial } \\
\text { Subparallel }\end{array}$ & 2.51 & 1.85 & Coarse & 0.37 & 0.46 & 0.17 & $\begin{array}{l}\text { Elongated-very } \\
\text { elongated }\end{array}$ & Low \\
\hline Cpl_28 & $\begin{array}{l}\text { Steep- } \\
\text { more gentle }\end{array}$ & Subparallel & 2.04 & 0.67 & Coarse & 0.55 & 0.68 & 0.37 & Circular-elongated & Moderate \\
\hline Cpl_29 & $\begin{array}{l}\text { Steep- } \\
\text { more gentle }\end{array}$ & Subparallel & 0.73 & 0.30 & $\begin{array}{l}\text { Very coarse- } \\
\text { coarse }\end{array}$ & 0.79 & 0.75 & 0.44 & $\begin{array}{l}\text { Circular-less } \\
\text { elongated }\end{array}$ & Moderate \\
\hline Cpl_30 & $\begin{array}{l}\text { More gentle- } \\
\text { gentle }\end{array}$ & Subparallel & 1.48 & 0.51 & $\begin{array}{l}\text { Very coarse- } \\
\text { coarse }\end{array}$ & 0.71 & 0.62 & 0.30 & Circular-elongated & Moderate \\
\hline Cpl_31 & $\begin{array}{l}\text { Steep- } \\
\text { more gentle }\end{array}$ & Subparallel & 2.23 & 0.81 & Coarse & 0.72 & 0.78 & 0.47 & $\begin{array}{l}\text { Circular-less } \\
\text { elongated }\end{array}$ & Moderate \\
\hline Cpl_32 & $\begin{array}{l}\text { Slightly steep- } \\
\text { gentle }\end{array}$ & $\begin{array}{l}\text { Subparallel } \\
\text { Subdendritic }\end{array}$ & 2.11 & 1.55 & Coarse & 0.68 & 0.71 & 0.39 & $\begin{array}{l}\text { Circular-less } \\
\text { elongated }\end{array}$ & Moderate \\
\hline Cpl_33 & Steep-gentle & Subparallel & 3.21 & 0.91 & Coarse & 0.64 & 0.58 & 0.26 & Circular-elongated & Moderate \\
\hline Cpl_34 & $\begin{array}{l}\text { Very steep- } \\
\text { gentle }\end{array}$ & $\begin{array}{l}\text { Subparallel } \\
\text { Subdendritic }\end{array}$ & 1.62 & 0.74 & $\begin{array}{l}\text { Very coarse- } \\
\text { coarse }\end{array}$ & 0.46 & 0.53 & 0.22 & Elongated & Moderate \\
\hline Cpl_35 & $\begin{array}{l}\text { Slightly steep- } \\
\text { gentle }\end{array}$ & Parallel & 1.97 & 0.42 & $\begin{array}{l}\text { Very coarse- } \\
\text { coarse }\end{array}$ & 0.45 & 0.49 & 0.19 & $\begin{array}{l}\text { Elongated-very } \\
\text { elongated }\end{array}$ & Low \\
\hline Cpl_36 & $\begin{array}{l}\text { More gentle- } \\
\text { gentle }\end{array}$ & Subdendritic & 3.83 & 1.06 & Coarse & 0.47 & 0.52 & 0.21 & Elongated & Low \\
\hline Cpl_37 & $\begin{array}{l}\text { More gentle- } \\
\text { gentle }\end{array}$ & Subdendritic & 3.53 & 1.13 & Coarse & 0.68 & 0.71 & 0.40 & $\begin{array}{l}\text { Circular-less } \\
\text { elongated }\end{array}$ & Moderate \\
\hline Cpl_38 & $\begin{array}{l}\text { More gentle- } \\
\text { gentle }\end{array}$ & Subdendritic & 3.15 & 0.79 & Coarse & 0.50 & 0.57 & 0.25 & Elongated & Low \\
\hline
\end{tabular}

Based on the results, the research area can be classified into 2 risk levels of flood potential, namely low and moderate risk levels (Table IV). The low-risk level of potential flood area is located in the northwestern of the research area; most of them are upstream of the Cipeles watershed in the Tanjungsari and Rancakalong district. The moderate risk level of potential flood area is located on the middle to downstream of the Cipeles watershed in the North Sumedang, South Sumedang, Situraja, and Cimalaka district.

The potential for flooding can be triggered by high rainfall. High rainfall in the Cipeles watershed upstream can cause high surface run-off and water-saturated conditions in the subsurface. This condition can cause flooding if the volume of river water is not well controlled. Therefore, several methods can be used to control the volume of river water and prevent flooding in the Cipeles watershed, namely integrated watershed management from upstream to downstream, land use management, erosion control, embankment construction, etc. Moreover, support from the local community is also necessary.

\section{CONCLUSION}

The flood-prone area in the Cipeles watershed can be identified by quantitative research through morphometric characteristics. Based on the morphometric analysis, Drainage density (Dd) values ranged from $0.73-4.05$, and Drainage texture $(\mathrm{Dt})$ values ranged from $0.23-3.84$. It indicates that all of the Cipeles subwatershed have very coarse-coarse texture. There is no apparent difference among Ratio of circularity (Rc), Ratio of elongation ( $\mathrm{Re}$ ), and Form 
factor (Rf). Ratio of circularity (Rc) ranged from 0.17-0.82. Ratio of elongation $(\mathrm{Re})$ ranged from $0.27-1.07$. Form factor values of subwatersheds are 0.06-0.89. In general, it indicates the subwatersheds have very elongated-circular shaped. Several places in the research area tend to be potentially flooded, especially in the middle to downstream of the Cipeles watershed. This is proven by the shape of the subwatersheds that show less elongated-circular shaped with very coarsecoarse texture. Moreover, high rainfall in the upstream of the subwatersheds can trigger flooding in the middle to downstream of the subwatersheds. The low-risk level of flood potential area is located on the northwestern of the research area, most of them are upstream of the Cipeles watershed. The moderate risk level of flood potential area is located in the middle to downstream of the Cipeles watershed. The results showed that quantitative research could be used to identify flood-prone areas. It is recommended that the Cipeles Watershed can be well maintained through integrated watershed management and land use management.

\section{ACKNOWLEDGMENT}

The authors are grateful to the Laboratory of Geomorphology and Remote Sensing, Faculty of Geological Engineering, Padjadjaran University, which has provided research facilities for us. The authors are also obliged to Padjadjaran University for assisting Internal Research Grants 2020.

\section{REFERENCES}

[1] S. Srinivasa Vittala, S. Govindaiah, and H. Honne Gowda, "Morphometric analysis of sub-watersheds in the pavagada area of Tumkur district, South India using remote sensing and gis techniques," J. Indian Soc. Remote Sens., 2004.

[2] D. W. Wulandari, E. Kusratmoko, and T. L. Indra, "Spatial model of land use change related to sediment yield (case study: Cipeles and Cilutung watershed, West Java)," IOP Conf. Ser. Earth Environ. Sci., vol. 149, no. $1,2018$.

[3] S. Y. Siswanto and F. Francés, "How land use/land cover changes can affect water, flooding and sedimentation in a tropical watershed: a case study using distributed modeling in the Upper Citarum watershed, Indonesia," Environ. Earth Sci., 2019.

[4] Chairil, R. A. Barkey, D. Malamassam, A. N. Mukhlisa, and M. Nursaputra, "Land use planning for floods mitigation in Kelara Watershed, South Sulawesi Province, Indonesia," IOP Conf. Ser. Earth Environ. Sci., vol. 575, no. 1, 2020.

[5] S. Sukristiyanti, R. Maria, and H. Lestiana, "Watershed-based Morphometric Analysis: A Review," in IOP Conference Series: Earth and Environmental Science, 2018.

[6] P. Mangan, M. A. Haq, and P. Baral, "Morphometric analysis of watershed using remote sensing and GIS - a case study of Nanganji River Basin in Tamil Nadu, India," Arab. J. Geosci., vol. 12, no. 6, 2019.

[7] A. Suharyanto, E. Suhartanto, and S. B. Lesmana, "Watershed morphometric classification analysis using geographic information system," Int. J. GEOMATE, 2020.

[8] P. Kumar Rai, V. Narayan Mishra, and K. Mohan, "A study of morphometric evaluation of the Son basin, India using geospatial approach," Remote Sens. Appl. Soc. Environ., 2017.

[9] M. Prama, A. Omran, D. Schröder, and A. Abouelmagd, "Vulnerability assessment of flash floods in Wadi Dahab Basin, Egypt," Environ. Earth Sci., 2020

[10] E. Sukiyah, E. Sunardi, N. Sulaksana, and P. P. Raditya Rendra, "Tectonic geomorphology of upper Cimanuk Drainage Basin, West Java, Indonesia," Int. J. Adv. Sci. Eng. Inf. Technol., vol. 8, no. 3, pp. 863-869, 2018 .

[11] D. Gentana, N. Sulaksana, E. Sukiyah, and E. T. Yuningsih, "Index of active tectonic assessment: Quantitative-based geomorphometric and morphotectonic analysis at Way Belu Drainage Basin, Lampung Province, Indonesia," Int. J. Adv. Sci. Eng. Inf. Technol., 2018.

[12] J. H. Abdulkareem, B. Pradhan, W. N. A. Sulaiman, and N. R. Jamil, "Quantification of Run-off as Influenced by Morphometric Characteristics in a Rural Complex Catchment," Earth Syst. Environ., vol. 2, no. 1, pp. 145-162, 2018.

[13] A. Balasubramanian, K. Duraisamy, S. Thirumalaisamy, S. Krishnaraj, and R. K. Yatheendradasan, "Prioritization of subwatersheds based on quantitative morphometric analysis in lower Bhavani basin, Tamil Nadu, India using DEM and GIS techniques," Arab. J. Geosci., vol. 10 , no. $24,2017$.

[14] G. Kabite and B. Gessesse, "Hydro-geomorphological characterization of Dhidhessa River Basin, Ethiopia," Int. Soil Water Conserv. Res., 2018.

[15] E. T. Haryanto, E. Sukiyah, P. P. Raditya Rendra, Hendarmawan, and Suratman, "Implication of catchment morphometric on small river discharge of upper Citarik river, West Java," Indones. J. Geogr., vol. 51, no. 2, pp. 224-230, 2019.

[16] P. Gunjan, S. K. Mishra, A. K. Lohani, and S. K. Chandniha, "The Study of Morphological Characteristics for Best Management Practices Over the Rampur Watershed of Mahanadi River Basin Using Prioritization," J. Indian Soc. Remote Sens., vol. 48, no. 1, pp. 35-45, 2020.

[17] A. D. Howard, "Drainage analysis in geologic interpretation: a summation," Am. Assoc. Pet. Geol. Bull., 1967.

[18] M. J. Nasir, J. Iqbal, and W. Ahmad, "Flash flood risk modeling of swat river sub-watershed: a comparative analysis of morphometric ranking approach and El-Shamy approach," Arab. J. Geosci., vol. 13, no. 20, 2020.

[19] N. Pant, R. K. Dubey, A. Bhatt, S. P. Rai, P. Semwal, and S. Mishra, Soil erosion and flood hazard zonation using morphometric and morphotectonic parameters in Upper Alaknanda river basin, vol. 103, no. 3. Springer Netherlands, 2020.

[20] O. Singh and D. Kumar, "Evaluating the influence of watershed characteristics on flood vulnerability of Markanda River basin in north-west India," Nat. Hazards, vol. 96, no. 1, pp. 247-268, 2019.

[21] S. H. Erena and H. Worku, "Flood risk analysis causes and landscape based mitigation strategies in Dire Dawa city, Ethiopia," Geoenvironmental Disasters, vol. 5, no. 1, 2018.

[22] M. Jothimani, Z. Dawit, and W. Mulualem, "Flood Susceptibility Modeling of Megech River Catchment, Lake Tana Basin, North Western Ethiopia, Using Morphometric Analysis," Earth Syst. Environ., no. 0123456789, 2020.

[23] D. L. Raja, E. Sukiyah, N. Sulaksana, and C. Endyana, "Morphometric and land use analysis to estimate flood hazard-A case study of upper Cimanuk Watershed in Garut Regency, Indonesia," Int. J. GEOMATE, 2020 .

[24] K. Ummah, E. Sukiyah, M. F. Rosana, and B. Y. C. S. S. Syah Alam, "Remote sensing identification of possible meteorite impact crater on Ciletuh, West Java," Int. J. Adv. Sci. Eng. Inf. Technol., 2018.

[25] A. R. B. Nugroho, E. Sukiyah, I. Syafri, and V. Isnaniawardhani, "Identification of tectonic deformation using morphometrical analysis of lamongan volcano complex," Int. J. GEOMATE, 2020.

[26] M. S. Karabulut and H. Özdemir, "Comparison of basin morphometry analyses derived from different DEMs on two drainage basins in Turkey," Environ. Earth Sci., vol. 78, no. 18, pp. 1-14, 2019.

[27] H. Riswandi, E. Sukiyah, B. Y. C. S. S. Syah Alam, and M. S. D. Hadian, "Morphotectonic identification utilizing satellite imagery processing on the southern part of Merapi Mount in Yogyakarta," Int. J. Adv. Sci. Eng. Inf. Technol., 2020.

[28] A. N. Strahler, "Quantitative Geomorphology of Drainage Basins and Channel Networks," in Handbook of Applied Hydrology, V. T. Chow, Ed. New York: McGraw-Hill, 1964, pp. 439-476.

[29] R. E. Horton, "Erosional development of streams and their drainage basins; Hydrophysical approach to quantitative morphology," Bull. Geol. Soc. Am., 1945.

[30] K. G. Smith, "Standards for grading texture of erosional topography," Am. J. Sci., 1950

[31] A. Malik, A. Kumar, and H. Kandpal, "Morphometric analysis and prioritization of sub-watersheds in a hilly watershed using weighted sum approach," Arab. J. Geosci., vol. 12, no. 4, 2019.

[32] S. A. Schumm, "Evolution of drainage systems and slopes in badlands at Perth Amboy, New Jersey," Bull. Geol. Soc. Am., 1956.

[33] M. Bauer et al., "Risk to residents, infrastructure, and water bodies from flash floods and sediment transport," Environ. Monit. Assess., vol. 191, no. 2, 2019. 
[34] X. Liu, S. Dang, C. Liu, and G. Dong, "Effects of rainfall intensity on the sediment concentration in the Loess Plateau, China," J. Geogr. Sci., vol. 30, no. 3, pp. 455-467, 2020.

[35] E. Arasaki, P. Alfredini, A. Pezzoli, and M. Rosso, "Coastal Area Prone to Extreme Flood and Erosion Events Induced by Climate Changes: Study Case of Juqueriquere River Bar Navigation, Caraguatatuba (Sao Paulo State), Brazil," TransNav Int. J. Mar. Navig. Saf. Sea Transp., vol. 6, no. 4, pp. 571-577, 2012.
[36] S. Zhu et al., "Conspicuous temperature extremes over Southeast Asia: seasonal variations under $1.5^{\circ} \mathrm{C}$ and $2{ }^{\circ} \mathrm{C}$ global warming," Clim. Change, 2020.

[37] M. Jayanti, Arwin, I. K. Hadihardadja, H. D. Ariesyady, and J. J. Messakh, "Climate change impacts on hydrology regime and water resources sustainability in Cimanuk watershed, West Java, Indonesia," Int. J. GEOMATE, 2020. 